\title{
Teachers' Preparedness for Lesson and Secondary School Student Academic Performance in Ekiti State, Nigeria
}

\author{
BOLARINWA Dapo Alonge \\ Department of Educational Management \\ Faculty of Education, Ekiti State University, PMB 5363, Ado-Ekiti, Ekiti State, Nigeria \\ AYODELE Joseph Babatola \\ Department of Educational Management \\ Faculty of Education, Ekiti State University, PMB 5363, Ado-Ekiti, Ekiti State, Nigeria \\ OLUSEGUN Grace Funmilayo \\ Department of Educational Guidance and Counselling \\ Faculty of Education, Ekiti State University, PMB 5363, Ado-Ekiti, Ekiti State, Nigeria \\ ABIODUN Eunice Olatide \\ Department of Social Science Education \\ Faculty of Education, Ekiti State University, PMB 5363, Ado-Ekiti, Ekiti State, Nigeria \\ AJAYI Olusola Akinola \\ Department of Educational Management \\ Faculty of Education, Ekiti State University, PMB 5363, Ado-Ekiti, Ekiti State, Nigeria
}

\begin{abstract}
The study examined the relationship between teachers' preparedness for lesson and secondary school student academic performance in Ekiti State, Nigeria. The purpose of the research is to find out the relationship between teachers' preparedness for lesson and secondary school student academic performance. The descriptive research of the survey type was employed for the study. The study revealed that the level of secondary school student academic performance was relatively moderate; there was significant relationship between teachers' preparedness for lesson and secondary school student academic performance. The study had shown that teachers' preparedness for lesson had influence on secondary school student academic performance.
\end{abstract}

Keywords: Teachers, Preparedness, Academic Performance, Lesson, Teachers' Preparedness

DOI: $10.7176 /$ RHSS/10-2-06

Publication date: January $31^{\text {st }} 2020$

\section{Introduction}

Student academic performance means different thing and this has led to a global debate around the concept. According to Achombo (2010), the issue of academic performance at schools has been of concern ever since modern education was introduced. Academic performance could be described as the scholastic standing of a student at a given examination. Omolayo (2009) argued that scholastic standing could be explained as the grades obtained in a course or group of courses taken. In collaboration with Omolayo (2009), Bello, Ibi and Bukar (2016) commented on the scholastic standing of students and argued that performance is a measure of output and that, the main outputs in education are expressed in terms of learning, that is, changes in knowledge, skills and attitudes of individuals as a result of their experiences within the school system.

According to Popoola (2017), there is no general agreement on how it is best tested or which aspects of most important procedural knowledge such as, skill or declarative knowledge such as, fact. It can be viewed that without students attempting either internal or external examination, it may be difficult to determine the academic performance effectiveness and vice versa. He also said, in educational institutions, success is measured by academic performance or how well a student meets standards set by the examination bodies; academic performance is largely identified by range of statistical indicators; and academic performance is a function of learning activity.

It has been observed that by the researchers that performance of students in public secondary schools in Ekiti State is below expectation in the external examinations. According to Oluwole (2017), in 2014 West African Schools Certificate Examination result (WASCE) conducted by the West African Examinations Council (WAEC), Ekiti State public secondary schools were occupying $12^{\text {th }}$ position; in 2015 , they managed to clinch the $11^{\text {th }}$ position and in 2016, they were occupying $11^{\text {th }}$ position against $28^{\text {th }}$ position in 2013. In 2017 and 2018, Ekiti State public secondary schools occupied $11^{\text {th }}$ position respectively (Department of Planning, Research and Statistics, Ministry of Education, Ado-Ekiti, Nigeria).

The researchers observed that some teachers were not studying the curriculum documents that can guide them 
in their teaching. Kimosop (2015) said, teachers need to prepare all the stages of the implementation of curriculum documents before they are actually used by the students through their assistance. This could affect student academic performance if not well implemented. The researchers also observed that some teachers were not having personal subject time-table which could help them to know when they are to enter class for their lesson, and the time to leave the class. It is only when the students come to inform them that they go the class. Some substantial parts of the lesson period would have been wasted by the time the teacher gets to the class. Therefore, it appears, ill-preparedness of a teacher for lesson could make it impossible for him to efficiently make use of time allocated to his lesson.

The researchers also observed that some teachers were not writing notes of lesson. It appears; teachers who do not write notes of lesson may not remember all salient points during teaching and may not be able to teach sequentially and logically. Oloruntegbe (1998) cited in Seweje and Dahunsi (2004) said, to develop an understanding of facts and concepts, the lesson must be well planned engendering adequate and purposeful interaction patterns. Datol and Pading (1996) cited in Jackden (2006) said, to avoid paraphrasing of lesson by teachers, careful preparation should be made and appropriate teaching method has to be adopted. More so, it seems, some teachers were not consulting necessary and relevant textbooks when preparing to teach new topics as teachers need to read many related textbooks before entering the class to teach in order to have good mastery of the subject matter and to be able to teach effectively. Therefore, teachers are supposed to be able to read ahead of their students. Jackden (2006) opined that a common cause of failure in teaching is the assumption that one can present his lesson without preparation due to familiarity with the subject. It has also been observed by the researchers that some teachers were not making use of instructional materials in their lesson as this is no doubt, a sign of ill-preparedness of lesson.

A study carried out by Goldhaber and Brewer (2000) titled, 'Does teacher certification matters? High school teacher certification status and student achievement' they found out that there was a positive relationship between teachers' preparation for lesson and students' academic performance. Also in a study carried out by DarlingHammond (1999) cited in Ajayi (2019) titled, ' 'Teacher quality and student achievement: A review of state policy evidence' ' he found out that there was a positive relationship between teachers' preparation for lesson and students' academic performance.

\section{Materials and Methods}

The descriptive research of the survey type was adopted for the study. The population of the study consisted of 11,991 Senior Secondary School III students and 185 school principals in Ekiti State public secondary schools (Source: Planning, Research and Statistics Department, Ekiti State Teaching Service Commission, Ado-Ekiti, Nigeria). The sample for the study was 1,200 students. Multistage sampling procedure was used for the study.

The first stage involved the use of stratified simple random sampling technique to select two Local Government Areas from each of the three Senatorial Districts. The second stage involved the use of simple random sampling technique to select four secondary schools from each of the six Local Government Areas randomly selected and this gives a total of 24 school principals. The third stage involved the use of a simple random sampling technique to select 50 students from each of the 24 secondary schools and this gives a total of 1,200 students. All the 24 school principals of the 24 secondary schools selected in stage two were used for the study.

\section{Results}

One research question and one research hypothesis were described and tested for the study respectfully as shown in tables 1 and 2 .

Table 1: Level of secondary school student academic performance

\begin{tabular}{|l|l|l|}
\hline Student Academic Performance & N & \multicolumn{1}{c|}{ Per Cent } \\
\hline 5 Credits and above & 924 & 41.4 \\
\hline 4 Credits & 472 & 21.1 \\
\hline 3 Credits & 252 & 11.3 \\
\hline Below 3 Credits & 584 & 26.2 \\
\hline Total & 2,232 & 100.0 \\
\hline
\end{tabular}

Table 1 presents the level of secondary school student academic performance. The result shows that 924 representing 41.4 per cent of the total enrolment of students who had five credits, 472 (21.1 per cent) had four credits while 252 ( 11.3 per cent) had three credits and 584 (26.2 per cent) had below three credits. This implies that the level of secondary school student academic performance is relatively moderate. 
Table 2: Test of relationship between teachers' preparedness for lesson and secondary school student academic performance

\begin{tabular}{|l|l|l|l|l|l|}
\hline Items & $\mathrm{N}$ & Mean & SD & $\mathrm{r}_{\text {cal }}$ & $\mathrm{r}_{\text {tab }}$ \\
\hline Teachers' preparedness for lesson & 24 & 16.99 & 0.79 & \multirow{2}{*}{$0.55^{*}$} & \multirow{2}{*}{0.05} \\
\cline { 1 - 5 } $\begin{array}{l}\text { Secondary school student academic } \\
\text { performance }\end{array}$ & 24 & 2.93 & 0.83 & \\
\hline
\end{tabular}

$* \mathrm{p}<0.05$ (significant result)

Table 2 shows the relationship between teachers' preparedness for lesson and secondary school student academic performance. The result obtained from the analysis shows that the value of $r$-calculated $(0.55)$ is greater than r-table value of (0.05). Therefore, the null hypothesis earlier formulated is rejected. This then means that there is significant positive relationship between teachers' preparedness for lesson and secondary school student academic performance of students.

\section{Discussion}

The study revealed that the level of secondary school student academic performance in Ekiti State was relatively moderate during the period under study. The relative moderate level of secondary school student academic performance might be as a result of teachers' preparedness for lesion, teachers' passion for job, teachers' fairness, teacher-student interaction and teachers' communication skills. This finding agrees with that of Oloruntegbe (1998) cited in Seweje and Dahunsi (2004) who said, for students to develop an understanding of facts and concepts, the lesson must be well planned engendering adequate and purposeful interaction patterns. This finding also agrees with that of Datol and Pading (1996) cited in Jackden (2006) who said, to avoid paraphrasing of lesson by teachers, careful preparation should be made and appropriate teaching method has to be adopted.

The study also revealed that there was significant positive relationship between teachers' preparedness for lesson and secondary school academic performance. This means that teachers' preparedness for lesson will enhance secondary school student academic performance. This might be as a result of use of instructional materials and lesson notes by the teacher during lesson and as a result of thorough supervision by the school heads. This finding is in support of Goldhaber and Brewer (2000) who found out there was a positive relationship between teachers' preparedness for lesson and students' academic performance. This finding also agrees with that of Darling-Hammond (1999) cited in Ajayi (2019) who found out that there was a positive relationship between teachers' preparedness for lesson and students' academic performance.

\section{Acknowledgements}

First and foremost, we sincerely appreciate the teachers and principals sampled in Ekiti State, Nigeria for this study, for their assistance and cooperation during the administration of the instrument. We thank the entire members of Ekiti Teaching Service Commission especially, Planning, Research and Statistics Department for releasing the West African School Certificate results. We acknowledge with thanks and immense gratitude, all the sources cited in this study and the ideas borrowed from published and unpublished sources. We cannot but express our sincere appreciation to Dr Bolarinwa Dapo Alonge for typing and sending the manuscript for reviewing.

We thank the Tertiary Education Trust Fund (TETFund) for providing enough funds for research despite the fact that we were unable to access the funds. May God bless the Agency abundantly (Amen).

\section{REFERENCES}

Achombo, C.N. (2010). Factors affecting the performance of pupils in primary schools in Paidhattown Council. Unpublished Masters Dissertation, Makerere University

Ajayi, O.A. (2019). Teacher factors as correlates of secondary school student academic performance in Ekiti State, Nigeria. Unpublished M.Ed Thesis in the Department of Educational Management, Faculty of Education, Ekiti State University, Ado-Ekiti, Nigeria.

Bello, S., Ibi, M.B. \& Bukar, I.B. (2016). Principals' administrative styles and students' academic performance in Taraba State, Nigeria. Journal of Education and Practice, 7 (18), 62-69.

Goldhaber, D.D. \& Brewer, D.J. (2000). Does teacher certification matters? High school teacher certification status and students' achievement. Educational Evaluation and Policy Analysis, 22 (2), 129-145.

Jackden, H.N. (2006). Effectiveness of methods used in teaching Technical Drawing in Federal College of Education, Pankshin, Nigeria. International Journal of Research in Education, 3 (2), 103-109.

Kimosop, E. (2015). Teacher preparedness for effective classroom instruction of the secondary school Christian Religious Education curriculum in Kenya. International Journal of Scientific Research and Innovative Technology, 2 (12), 1-10.

Darling-Hammond, L. (2000). Teacher quality and students' achievement. Education Policy Analysis Archives, 10 (36), 16-38.

Oluwole, J. (2017, September 3). Analysis: WAEC rating highlights dwindling fortunes of education in Southwest, 
Nigeria. Premium Times, Nigeria (online).

Omolayo, B. (2009). Effect of leadership styles on job related tension and psychological sense of community in work organisation: Case study of four organisations in Lagos State, Nigeria. Bangladesh Educational Journal of Social Sciences, 4(2), 133-157. 